OPEN

SUBJECT AREAS: ELECTROCHEMISTRY

APOPTOSIS

Received

27 December 2013

Accepted

24 February 2014

Published

14 March 2014

Correspondence and requests for materials should be addressed to Z.Y.W. (zywu@ipp.ac. cn) or X.Z. (xinzhang@ ahau.edu.cn)

* These authors contributed equally to this work.

\section{Facile and quantitative electrochemical detection of yeast cell apoptosis}

\author{
Qiulin Yue ${ }^{*}$, Shiquan Xiong ${ }^{2 *}$, Dongqing $\mathrm{Cai}^{2}$, Zhengyan $\mathrm{Wu}^{2}$ \& Xin Zhang ${ }^{1}$
}

${ }^{1}$ School of Life Sciences, Anhui Agricultural University, Hefei 230036, People's Republic of China, ${ }^{2}$ Key Laboratory of lon Beam Bioengineering, Hefei Institutes of Physical Science, Chinese Academy of Sciences, Hefei 230031, People's Republic of China.

An electrochemical method based on square wave anodic stripping voltammetry (SWASV) was developed to detect the apoptosis of yeast cells conveniently and quantitatively through the high affinity between $\mathrm{Cu}^{2+}$ and phosphatidylserine (PS) translocated from the inner to the outer plasma membrane of the apoptotic cells. The combination of negatively charged PS and $\mathrm{Cu}^{2+}$ could decrease the electrochemical response of $\mathrm{Cu}^{2+}$ on the electrode. The results showed that the apoptotic rates of cells could be detected quantitatively through the variations of peak currents of $\mathrm{Cu}^{2+}$ by SWASV, and agreed well with those obtained through traditional flow cytometry detection. This work thus may provide a novel, simple, immediate and accurate detection method for cell apoptosis.

poptosis is a vital cellular process of programmed cell death and it is critically involved in both normal development and the pathogenesis of a wide variety of diseases ${ }^{1,2}$. It is also a morphologically distinct form of cell death that is crucial for embryogenesis, tissue homeostasis, and disease control in multicellular organisms. The process of apoptosis can be influenced by a diverse range of either endogenous or exogenous stimuli $^{3-6}$, trigger different intracellular signal transduction pathways ${ }^{7-9}$.

Detection of apoptosis is of great importance in many areas of biological research. It could be considered as an indicator for the effect of therapeutic interventions and disease progression ${ }^{10,11}$. Some characteristic cell morphology changes (such as cell shrinkage, cell cycle changes, and nuclear fragmentation) and apoptotic markers (such as chromatin condensation, DNA fragmentation, phosphatidylserine (PS) externalization, and cytochrome $c$ release from mitochondria, etc.) are routine detection items in cells to identify the apoptotic processes ${ }^{2,12}$. Several methods have been developed for apoptosis detection ${ }^{9}$, such as electron microscopy ${ }^{13}$, spectroscopic techniques $^{14,15}$, flow cytometry ${ }^{14,16,17}$, TUNEL assay ${ }^{18,19}$, single-molecule spectroscopy ${ }^{20}$, and microfluidic devices ${ }^{21,22}$, etc. However, these methods are usually time-consuming and require sophisticated instrumentation and technical expertise. It is necessary to search for a rapid, sensitive and simple method to detect apoptosis. Electrochemical method, as a simple and convenient technique, could be a promising approach compared with those methods. In recent years, detection of cell apoptosis by some electrochemical methods have been reported ${ }^{23-26}$. Based on the specific interaction between Annexin V and $\mathrm{PS}^{14}$, electrochemical detection of externalized PS in the early apoptotic process is mostly employed. Liu et al. prepared an Annexin V and polyethylenimine (PEI) comodified electrode to electrochemically detect PS exposing to the outer leaflet of the plasma membrane ${ }^{23}$. However, Annexin $\mathrm{V}$ is rather expensive and those electrochemical methods mainly focus qualitative detection. Therefore, it is important to develop an quantitative electrochemical detection method with low cost and convenience.

It is known that $\mathrm{Cu}^{2+}$ forms a 1:2 complex with PS in solution containing water, methanol and chloroform ${ }^{27}$, and the interaction between PS and $\mathrm{Cu}^{2+}$ could be detected ${ }^{28}$. Therefore, based on such characteristic, an electrochemical method was herein developed through square wave anodic stripping voltammetry (SWASV) to detect cell apoptosis in $\mathrm{Cu}^{2+}$ solution. When apoptotic cells were added into $\mathrm{Cu}^{2+}$ solution, the exposed PS could combine $\mathrm{Cu}^{2+}$, and the SWASV peak current of $\mathrm{Cu}^{2+}$ was influenced. In light of the current variation, detection of cell apoptosis becomes available.

In the present study, we described for the first time that apoptosis of yeast cells were quantitatively detected using SWASV method. Saccharomyces cerevisiae (S. cerevisiae) was selected as an in vivo model system to study the apoptotic cell on biochemical process ${ }^{29}$. At the same time, traditional flow cytometry assay was carried out and proved the reliability of the above electrochemical method. Therefore, detection of apoptosis based on SWASV response of $\mathrm{Cu}^{2+}$ may offer a sensitive and feasible method to determine apoptotic cells conveniently, inexpensively and quantitatively. 

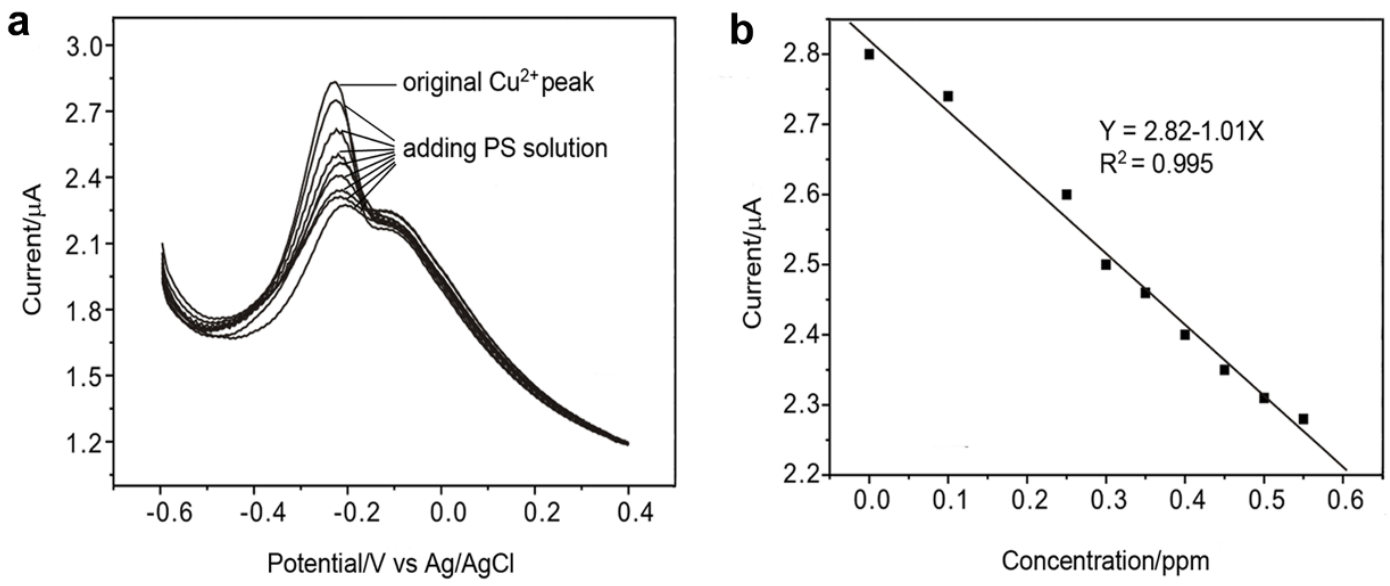

Figure $1 \mid$ (a) SWASV responses of $\mathrm{Cu}^{2+}$ with successive addition of standard PS over a concentration range of 0 to $0.55 \mathrm{ppm}$ in $0.1 \mathrm{M}$ Tris-HCl buffer solution ( $\mathrm{pH}$ 8.2). (b) Dependence of peak current on the concentration of PS. Deposition potential, -0.6 V; deposition time, $120 \mathrm{s.}$

\section{Results}

First, to detect PS sensitively by electrochemical method, 1,10-diaminodecane (DAD) was used to modify glassy carbon electrode (GCE). As shown in Figure S1, after a bare GCE was immersed into DAD ethanol solution, there was an obvious anodic peak shown in the first cycle (line 1), and the anodic peak disappeared at the second cycle (line 2), which indicated the DAD was formed on the electrode surface and the film blocked further oxidation of $\mathrm{DAD}^{30}$. The electrochemical impedance spectra of the electrodes were also obtained (see Figure S2). To obtain the largest response of detection, a series of experimental conditions containing $\mathrm{pH}$, deposition time, supporting electrolytes, and deposition potential were optimized (see Figure S3). The detection system with $\mathrm{pH}$ of 8.2, deposition time of $120 \mathrm{~s}, 0.1 \mathrm{M}$ Tris-HCl buffer solution as supporting electrolyte and deposition potential of $-0.6 \mathrm{~V}$ were chosen as the optimal parameters of SWASV throughout the study.

Standard PS (5 mg) was added into $10 \mathrm{~mL}$ of $0.1 \mathrm{M}$ Tris- $\mathrm{HCl}$ buffer solution making a standard PS solution of $0.5 \mathrm{mg} / \mathrm{mL}$, and each of $20 \mu \mathrm{L}$ of PS solution was added into $0.6 \mathrm{ppm} \mathrm{Cu}^{2+}$ solution. Figure la showed the SWASV responses of the DAD/GC electrode to successive addition of standard PS solution. Anodic stripping peak appeared at approximately $-0.21 \mathrm{~V}$. It could be seen PS specifically combined $\mathrm{Cu}^{2+}$ in solution, consequently the $\mathrm{Cu}^{2+}$ peak currents were decreased compared with PS free system, and diminished linearly with the addition of PS ranging from 0 to $0.55 \mathrm{ppm}$ (Figure 1b).



The results demonstrated that the varying amounts of PS molecules could be detected by SWASV.

Since the discovery of yeast apoptosis in $1997^{29}$, several studies had shown that apoptosis might also occur in unicellular organisms besides mammalian cells. $\mathrm{H}_{2} \mathrm{O}_{2}$ can induce apoptosis in $S$. cerevisiae as well as in mammalian cells $\mathrm{s}^{31,32}$. As shown in Figure S4, in our study, after treated with $1 \mathrm{mM} \mathrm{H}_{2} \mathrm{O}_{2}$ for $200 \mathrm{~min}$, S. cerevisiae cells viability evaluated by colony formation decreased to approximately $30 \%$, and even lower with higher concentrations of $\mathrm{H}_{2} \mathrm{O}_{2}$ ( $3 \mathrm{mM}$ and $5 \mathrm{mM}$ ). Obviously, $\mathrm{H}_{2} \mathrm{O}_{2}$ caused apoptotic cell death in a concentrationdependent manner. The result was consistent with previous findings, and this apoptotic cell death appeared as the exposure of $\mathrm{PS}^{29,31,33}$.

Figure 2a presented the SWASV electrochemical responses of $\mathrm{Cu}^{2+}$ before and after successive addition of $\mathrm{H}_{2} \mathrm{O}_{2}$ treated yeast cell solution in $0.1 \mathrm{M}$ Tris- $\mathrm{HCl}$ solution ( $\mathrm{pH} \mathrm{8.2).} \mathrm{The} \mathrm{highest} \mathrm{peak}$ current was obtained when $\mathrm{Cu}^{2+}$ in pure Tris- $\mathrm{HCl}$ solution, and then the peak currents decreased gradually with successive addition of $20 \mu \mathrm{L}$ of $1 \mathrm{mM} \mathrm{H}_{2} \mathrm{O}_{2}$ treated apoptotic yeast cells solution. For comparison, normal yeast cells were added into $\mathrm{Cu}^{2+}$ solution, and the peak currents showed no obvious change (Figure $2 b$ ), since there were no PS molecules on the outer membrane of the nonapoptotic cells.

Figure 3 depicted the classical flow cytometric analysis of PS externalization by FITC-Annexin V/PI costained S. cerevisiae cells after a 200 min treatment with ethanol (Figure 3a) and different

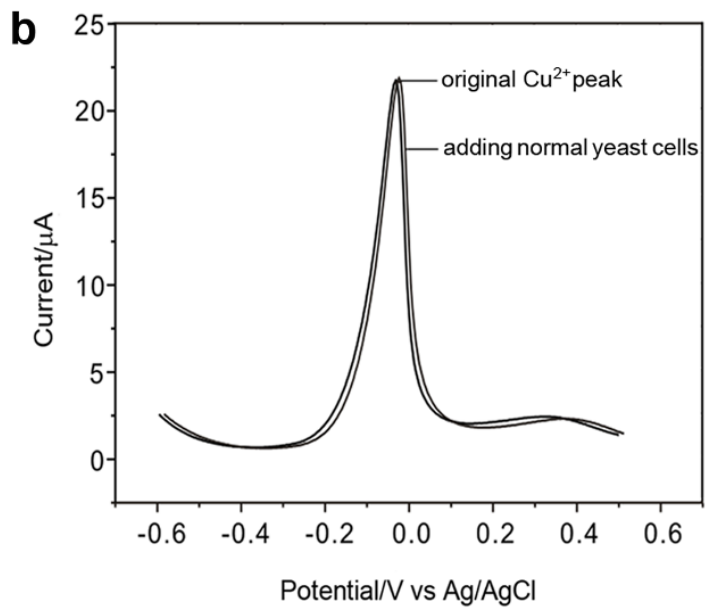

Figure $2 \mid$ SWASV electrochemical responses of $\mathrm{Cu}^{2+}$ of actual cells. (a) With successive addition of $20 \mu \mathrm{L}$ of $1 \mathrm{mM} \mathrm{H}_{2} \mathrm{O}_{2}$ treated apoptotic yeast cell solution. (b) With addition of normal yeast cell in $0.1 \mathrm{M}$ Tris- $\mathrm{HCl}$ solution ( $\mathrm{pH}$ 8.2). SWASV conditions: frequency, $15 \mathrm{~Hz}$; potential step, $4 \mathrm{mV}$; pulse amplitude, $25 \mathrm{mV}$. 



Figure 3 Flow cytometric analysis of PS externalization by FITC-Annexin V/PI costained $S$. cerevisiae cells after a 200 min treatment with (a) ethanol, (b) $1 \mathrm{mM} \mathrm{H}_{2} \mathrm{O}_{2}$, (c) $3 \mathrm{mM} \mathrm{H}_{2} \mathrm{O}_{2}$, and (d) $5 \mathrm{mM} \mathrm{H}_{2} \mathrm{O}_{2}$.

concentration of $\mathrm{H}_{2} \mathrm{O}_{2}$ (Figure $3 \mathrm{~b}-\mathrm{d}$ ). In each diagram, two separated regions ("negative" and "positive") could be seen. The peak area of "positive" region represented the number of $\mathrm{AV}^{+}$cells, namely apoptotic cells, while that of the "negative" region denoted the viable or necrotic cells. The results indicated that the ratio of apoptotic cells treated with ethanol, $1 \mathrm{mM}, 3 \mathrm{mM}$ and $5 \mathrm{mM}$ $\mathrm{H}_{2} \mathrm{O}_{2}$ were $9.52 \%, 26.87 \%, 36.64 \%$ and $55.05 \%$, respectively.

The apoptosis of the treated yeast cells were also detected through SWASV as shown in Figure 4. The peak current of electrochemical response decreased $1.4 \mu \mathrm{A}$ with addition of $20 \mu \mathrm{L}$ of ethanol treated cells solution (Figure $4 \mathrm{a}$ ), $4.8 \mu \mathrm{A}$ with $20 \mu \mathrm{L}$ of $1 \mathrm{mM} \mathrm{H}_{2} \mathrm{O}_{2}$ treated cells solution (Figure 4b), $7.6 \mu \mathrm{A}$ with $20 \mu \mathrm{L}$ of $3 \mathrm{mM} \mathrm{H}_{2} \mathrm{O}_{2}$ treated cells solution (Figure 4c), and $10.3 \mu \mathrm{A}$ with $20 \mu \mathrm{L}$ of $5 \mathrm{mM}$ $\mathrm{H}_{2} \mathrm{O}_{2}$ treated cells solution (Figure $4 \mathrm{~d}$ ), respectively. When the ratio of peak current decrease was set as the quantitative analysis index of the ratio of apoptotic cells, the ratios in four treatments were $6.67 \%$, $22.86 \%, 36.19 \%$ and $49.05 \%$, respectively.

\section{Discussion}

Orij et al. reported that $S$. cerevisiae's physiological $\mathrm{pH}$ range was 7.27.5 , which was in response to the nutrient availability and respiratory chain activity ${ }^{34}$. PS lipids are found in a wide variety of cell types, and it is an important signaling molecule in clotting, apoptosis, and embryonic development ${ }^{35}$. PS bears a negative charge at physiological $\mathrm{pH}$. Monson et al. found that PS could reversibly bind $\mathrm{Cu}^{2+}$ with extremely high affinity in a $\mathrm{pH}$-dependent fashion ${ }^{28}$. The $\mathrm{pH}$ value used in our study was 8.2, which was not far away from yeast physiological $\mathrm{pH}$ and thus scarcely affected yeast apoptosis.
Therefore, on the basis of the specifical interaction between $\mathrm{Cu}^{2+}$ and PS, electrochemical detection of apoptosis becomes available.

Previous investigation showed that $1 \sim 3 \mathrm{mM} \mathrm{Cu}^{2+}$ might be beneficial for cell growth after $24 \mathrm{~h}$ of incubation, whereas the extensive apoptosis occured at $6 \mathrm{mM} \mathrm{Cu}^{2+}$, and apoptosis was largely replaced by necrosis at $10 \mathrm{mM} \mathrm{Cu}^{2+36}$. Therefore, low concentration of $\mathrm{Cu}^{2+}$ in our study (less than $1 \mathrm{mM}$, actually $0.6 \mathrm{ppm}$ ) and rapidly detection could make the effect of $\mathrm{Cu}^{2+}$ on cell growth ignored.

To confirm the cell apoptosis could be detected by SWASV method, influence of PS alone on $\mathrm{Cu}^{2+}$ needs to be first tested through SWASV. With the modified DAD/GC electrode, the $\mathrm{Cu}^{2+}$ peak currents in solution and additional standard PS content showed a linear correlation relationship (Figure 1). It was obvious that the amounts of $\mathrm{Cu}^{2+}$ deposited on the electrode decreased because of binding with PS.

In actual cells, PS molecules are normally located on the inner membrane. The normal yeast cells had scarcely any externalized PS molecules, thus would not affect the SWASV responses of $\mathrm{Cu}^{2+}$ (Figure 2b). PS can be externalized in the early stage of the apoptosis process $^{16}$. Once PS exposed to the extracellular environment, it could interact with some cations. In the present study, $\mathrm{H}_{2} \mathrm{O}_{2}$ induced apoptosis in S. cerevisiae, and released PS in the test solution can result in the change of $\mathrm{CVs}$ of the electrochemical response of $\mathrm{Cu}^{2+}$ (Figure 2a). Therefore, we could get to know whether the test cells are apoptotic cells, since apoptotic cells will make an obvious CV change, while healthy or necrotic cells will not.

In order to evaluate the feasibility and accuracy of SWASV method in quantitative detection and analysis of apoptotic process, yeast cells 

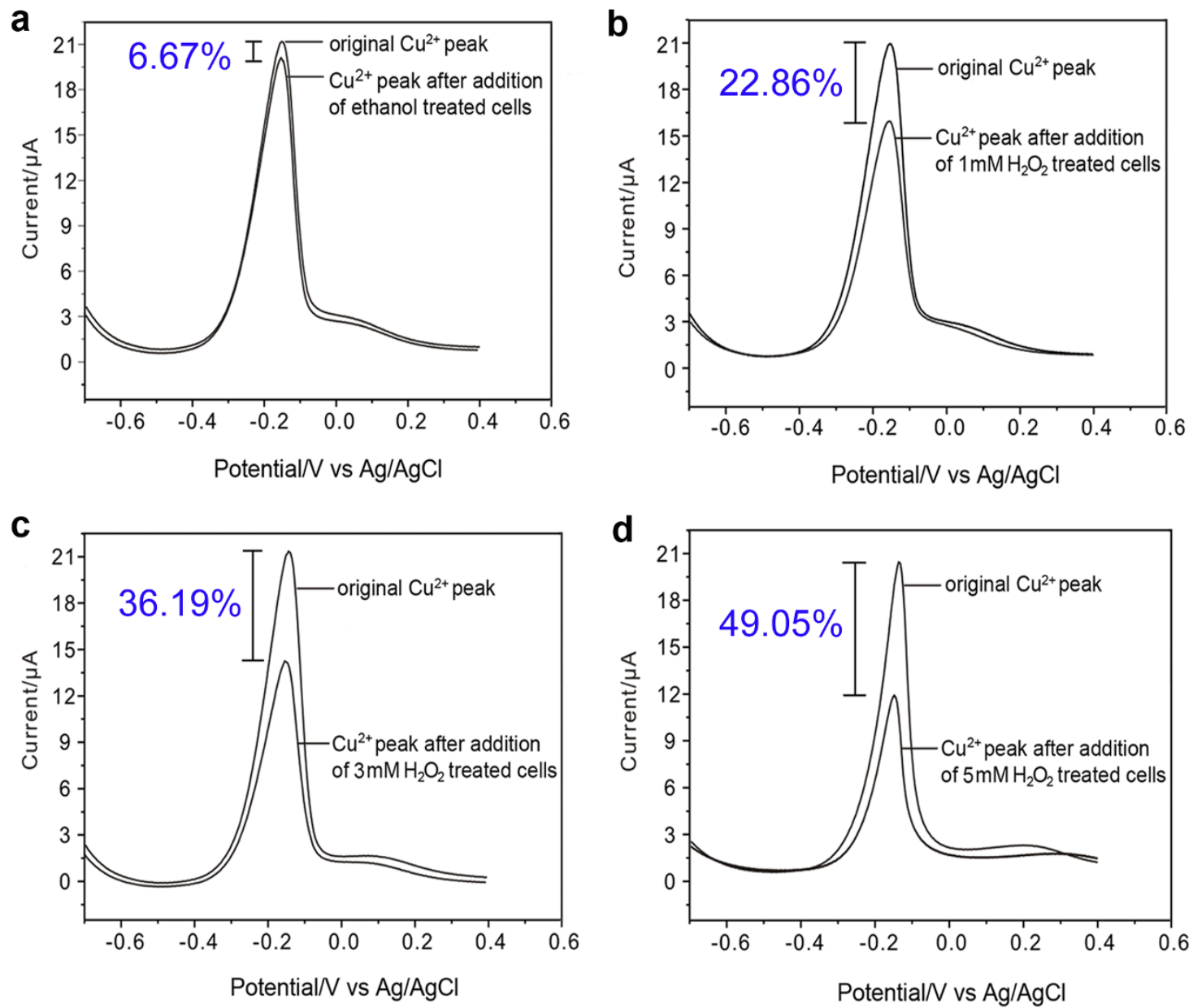

Figure $4 \mid$ SWASV responses of $\mathrm{Cu}^{2+}$ of apoptotic $S$. cerevisiae cells in $0.1 \mathrm{M}$ Tris- $\mathrm{HCl}$ solution (pH 8.2). The cell treatments are same as Figure 3 .

treated with ethanol and $\mathrm{H}_{2} \mathrm{O}_{2}$ were separately detected by flow cytometry (Figure 3) and SWASV (Figure 4). Because the number of cells with surface-exposed PS was related to the signal response of detection, same amount of apoptotic yeast cells $\left(1 \times 10^{4} \mathrm{~S}\right.$. cerevisiae cells) were detected in the present study by two technologies, and the ratios of the apoptotic cells were both analyzed.

Obviously, compared with the control experiment, as the degree of cell apoptosis increased, more exposed PS molecules interacted with $\mathrm{Cu}^{2+}$ in solutions and caused the greater decrease of $\mathrm{Cu}^{2+}$ peak current. The results obtained with SWASV were well consistent with that from flow cytometry, indicating this electrochemical technique could detect the ratio of apoptotic cells accurately. The values from SWASV were slightly lower than that from flow cytometric detection, this might be because the electrochemical detection is rapid and immediately and does not need the time-consuming stain process, whereas stains probably influence cell apoptosis at a certain degree $^{9,24}$.

In conclusion, we developed a novel and simple strategy to detect yeast apoptosis quantitatively by an electrochemical method, SWASV, instead of the usage of expensive fluorescent labeled protein, Annexin V. The declines of peak currents were in response to the high affinity between $\mathrm{Cu}^{2+}$ and PS externalization from apoptotic cells. Experimental results showed that the SWASV responses diminished with addition of PS continuously, and the results were also well consistent with that obtained from flow cytometry. SWASV detection procedure could not only easily perform and quantitatively reflect the ratio of apoptotic cells, but also accurately represent the instantaneous situation of cell apoptosis. To a certain extent, it has some advantages over the traditional methods. With cost-efficiency, simplicity and accuracy, this electrochemical technique may have great potentials for detecting cell apoptosis, not only in vitro, but also in vivo systems.

\section{Methods}

Materials. S. cerevisiae strain 1812 (MATa) was purchased from China Center of Industrial Culture Collection (Beijing, China). PS was purchased from Sigma-Aldrich Company (St. Louis, USA). FITC Annexin V Apoptosis Detection Kit I (556547) was purchased from BD Pharmingen Company (San Diego, USA). Stock solutions of $\mathrm{H}_{2} \mathrm{O}_{2}$ were used at a concentration of $250 \mathrm{mM}$ in $100 \%$ ethanol and stored at $4{ }^{\circ} \mathrm{C}$ before assays. 1,10-Diaminodecane (DAD) was obtained from Aike Chemical Reagent Company (Chengdu, China). Other chemicals were of analytical grade. All solutions were prepared with deionized water purified by a Milli-Q purification system (Millipore, USA), and stored in a refrigerator at $4^{\circ} \mathrm{C}$.

Yeast cell culture and apoptosis induced by $\mathrm{H}_{2} \mathrm{O}_{2}$. Yeast cells were grown at $30^{\circ} \mathrm{C}$ in $30 \mathrm{~mL}$ of YPD medium (1\% yeast extract, $2 \%$ glucose, $2 \%$ peptone). For each experiment, the cultures were inoculated with an overnight culture (exponential phase) to an $\mathrm{OD}_{600}$ of 0.1 (approximately $1 \times 10^{6} \mathrm{cells} / \mathrm{mL}$ ). To induce yeast apoptosis, three samples (each $1 \mathrm{~mL}$ of exponential yeast cells in a $2 \mathrm{~mL}$ tube) were separately incubated with $20 \mu \mathrm{L}$ of $\mathrm{H}_{2} \mathrm{O}_{2}$ dissolved in ethanol with different concentrations $\left(1 \mathrm{mM}, 3 \mathrm{mM}\right.$, and $5 \mathrm{mM}$ ) at $30^{\circ} \mathrm{C}$ for $200 \mathrm{~min}$, and a sample with pure ethanol treatment was set as a control. After $200 \mathrm{~min}$, cells were harvested at $6000 \mathrm{rpm}$ for $3 \mathrm{~min}$.

Yeast cell survival assay. Cell survival was determined by plating aliquots of cell suspensions diluted in saline $(1: 1000)$ onto YPD agar plates with an YLN-50 colony counter (YLN Electromechanical Technology Research Institute, China). For calculation of death rates, the control was set to $100 \%$ survival under the same condition. Colony-forming units were determined after incubating the plates for $48 \mathrm{~h}$ at $30^{\circ} \mathrm{C}$. At least three replicates of viability tests were performed.

Apoptosis assay by flow cytometry. Before electrochemical detection was conducted, traditional Annexin V/PI costaining on apoptotic yeast cells was performed. Spheroplasts of cells induced by different concentration of $\mathrm{H}_{2} \mathrm{O}_{2}$ were stained with 
FITC-labeled Annexin V and PI using a FITC-Annexin V apoptosis detection kit as described in the technical data sheet. After treated with Annexin V-FITC, $1 \times 10^{4}$ cells were analyzed with a FACSCalibur flow cytometry system (BD Biosciences Co., USA) accompanied with Cell Quest Pro software.

Preparation of DAD modified glassy carbon electrode. To detect $\mathrm{Cu}^{2+}$ sensitively, DAD was used to modify glassy carbon electrode (GCE). Prior to modification, the GCE was carefully polished with $1,0.3,0.05 \mu \mathrm{m}$ alumina slurry, cleaned with ethanol and deionized water and dried in nitrogen. Afterwards, the GCE was immersed into $8 \mathrm{mM}$ DAD ethanol solution containing $0.1 \mathrm{M} \mathrm{LiClO}_{4}$ and the potential was applied from 0 to $1.6 \mathrm{~V}$ for two times at a scan rate of $15 \mathrm{mV} \mathrm{s}^{-1}$, then a DAD modified GCE was obtained.

Detection of $\mathrm{Cu}^{2+}$ and apoptosis by SWASV. Detection of $\mathrm{Cu}^{2+}$ was carried out by SWASV (frequency $=15 \mathrm{~Hz}$, sensitivity $=4 \mathrm{mV}$, amplitude $=25 \mathrm{mV}$ ) in Tris- $\mathrm{HCl}$ buffer solution (0.1 M, pH 8.2). As for apoptosis detection, $20 \mu \mathrm{L}$ of $\mathrm{H}_{2} \mathrm{O}_{2}$ treated yeast solution (approximately $1 \times 10^{4}$ cells) was added into $\mathrm{Cu}^{2+}$ solution and stirred for $2 \mathrm{~min}$, and then the electrochemical responses of the $\mathrm{DAD} / \mathrm{GC}$ electrode were recorded. The experiments were performed at least in triplicate.

Electrochemical apparatus. Electrochemical experiments were recorded using a $\mathrm{CHI}$ 660D computer-controlled electrochemical workstation (CH Instruments, USA) with a standard three-electrode system. The DAD modified GCE served as a working electrode; a platinum wire was used as a counter-electrode with a saturated $\mathrm{Ag} / \mathrm{AgCl}$ electrode completing the cell assembly. A pH meter (Mettler Toledo FE20, Switzerland) was used for measuring $\mathrm{pH}$

1. Thompson, C. B. Apoptosis in the pathogenesis and treatment of disease. Science 267, 1456-1462 (1995).

2. Elmore, S. Apoptosis: A review of programmed cell death. Toxicol. Pathol. 35, 495-516 (2007).

3. Lukiw, W. J. \& Bazan, N. G. Inflammatory, apoptotic, and survival gene signaling in Alzheimer's Disease. Mol. Neurobiol. 42, 10-16 (2010).

4. Lacaille-Dubois, M.-A., Pegnyemb, D. E., Noté, O. P. \& Mitaine-Offer, A.-C. A review of acacic acid-type saponins from Leguminosae-Mimosoideae as potent cytotoxic and apoptosis inducing agents. Phytochem. Rev. 10, 565-584 (2011).

5. Potten, C. S. \& Booth, C. The role of radiation-induced and spontaneous apoptosis in the homeostasis of the gastrointestinal epithelium: a brief review. Comp. Biochem. Physiol., Part B: Biochem. Mol. Biol. 118, 473-478 (1997).

6. Reiter, J., Herker, E., Madeo, F. \& Schmitt, M. Viral killer toxins induce caspasemediated apoptosis in yeast. J. Cell Biol. 168, 353-358 (2005).

7. Fadeel, B. \& Orrenius, S. Apoptosis: a basic biological phenomenon with wideranging implications in human disease. J. Intern. Med. 258, 479-517 (2005).

8. Benderska, N. et al. Apoptosis signalling activated by TNF in the lower gastrointestinal tract - review. Curr. Pharm. Biotechnol. 13, 2248-2258 (2012).

9. Martinez, M. M., Reif, R. D. \& Pappas, D. Detection of apoptosis: A review of conventional and novel techniques. Anal. Methods 2, 996-1004 (2010).

10. Brown, J. M. \& Attardi, L. D. Opinion - The role of apoptosis in cancer development and treatment response. Nat. Rev. Cancer 5, 231-237 (2005).

11. van Tilborg, G. A. F. et al. Annexin A5-functionalized bimodal lipid-based contrast agents for the detection of apoptosis. Bioconjugate Chem. 17, 741-749 (2006).

12. Madeo, F. et al. Apoptosis in yeast. Curr. Opin. Microbiol. 7, 655-660 (2004).

13. Otsuki, Y., Li, Z. \& Shibata, M.-A. Apoptotic detection methods - from morphology to gene. Progr. Histochem. Cytochem. 38, 275-340 (2003).

14. Koopman, G. et al. Annexin V for flow cytometric detection of phosphatidylserine expression on B cells undergoing apoptosis. Blood 8, 1415-1420 (1994).

15. Gatti, R. et al. Comparison of annexin V and calcein-AM as early vital markers of apoptosis in adherent cells by confocal laser microscopy. Histochem. Cytochem. 46, 895-900 (1998).

16. van England, M., Nieland, L. J., Ramaekers, F. C., Schutte, B. \& Reutelingsperger, C. P. Annexin V-affinity assay: a review on an apoptosis detection system based on phosphatidylserine exposure. Cytometry 31, 1-9 (1998)

17. Yasuhara, S. et al. Comparison of comet assay, electron microscopy, and flow cytometry for detection of apoptosis. J. Histochem. Cytochem. 51, 873-885 (2003).

18. Gavrieli, Y., Sherman, Y. \& Ben-Sasson, S. A. Identification of programmed cell death in situ via specific labeling of nuclear DNA fragmentation. J. Cell. Biol. 119, 493-501 (1992).
19. Ray, S. K., Schaecher, K. E., Shields, D. C., Hogan, E. L. \& Banik, N. L. Combined TUNEL and double immunofluorescent labeling for detection of apoptotic mononuclear phagocytes in autoimmune demyelinating disease. Brain Res. Protoc. 5, 305-311 (2000).

20. Kasili, P. M., Song, J. M. \& Vo-Dinh, T. Optical sensor for the detection of caspase9 activity in a single cell. J. Am. Chem. Soc. 126, 2799-2806 (2004).

21. Valero, A. et al. Apoptotic cell death dynamics of HL60 cells studied using a microfluidic cell trap device. Lab Chip 5, 49-55 (2005).

22. Wu, G. et al. Assay development and high-throughput screening of caspases in microfluidic format. Comb. Chem. High T. Scr. 6, 303-312 (2003).

23. Liu, T. et al. Detection of apoptosis based on the interaction between Annexin $\mathrm{V}$ and phosphatidylserine. Anal. Chem. 81, 2410-2413 (2009).

24. Tong, C. Y. et al. An Annexin V-based biosensor for quantitatively detecting early apoptotic cells. Biosens. Bioelectron. 24, 1777-1782 (2009).

25. Xiao, H., Liu, L., Meng, F. B., Huang, J. Y. \& Li, G. X. Electrochemical approach to detect apoptosis. Anal. Chem. 80, 5272-5275 (2008).

26. Zhang, J. J., Zheng, T. T., Cheng, F. F., Zhang, J. R. \& Zhu, J. J. Toward the early evaluation of therapeutic effects: An electrochemical platform for ultrasensitive detection of apoptotic cells. Anal. Chem. 83, 7902-7909 (2011).

27. Shirane, K., Kuriyama, S. \& Tokimoto, T. Synergetic effects of $\mathrm{Ca}^{2+}$ and $\mathrm{Cu}^{2+}$ on phase transition in phosphatidylserine membranes. Biochim. Biophys. Acta 769, 596-600 (1984)

28. Monson, C. F. et al. Phosphatidylserine reversibly binds $\mathrm{Cu}^{2+}$ with extremely high affinity. J. Am. Chem. Soc. 134, 7773-7779 (2012).

29. Madeo, F., Fröhlich, E. \& Fröhlich, K.-U. A yeast mutant showing diagnostic markers of early and late apoptosis. J. Cell Biol. 139, 729-734 (1997).

30. Liu, J. Y. \& Dong, S. J. Grafting of diaminoalkane on glassy carbon surface and its functionalization. Electrochem. Commun. 2, 707-712 (2000).

31. Madeo, F. et al. Oxygen stress: a regulator of apoptosis in yeast. J. Cell Biol. 145, 757-767 (1999).

32. Daroui, P., Desai, S. D., Li, T.-K., Liu, A. A. \& Liu, L. F. Hydrogen peroxide induces topoisomerase I-mediated DNA damage and cell death. J. Biol. Chem. 279, 14587-14594 (2004).

33. Ahn, S.-H. et al. Sterile 20 kinase phosphorylates histone H2B at serine 10 during hydrogen peroxide-induced apoptosis in S. cerevisiae. Cell 120, 25-36 (2005).

34. Orij, R., Postmus, J., Beek, A. T., Brul, S. \& Smits, G. J. In vivo measurement of cytosolic and mitochondrial $\mathrm{pH}$ using a $\mathrm{pH}$-sensitive GFP derivative in Saccharomyces cerevisiae reveals a relation between intracellular $\mathrm{pH}$ and growth. Microbiology 155, 268-278 (2009).

35. Leventis, P. A. \& Grinstein, S. The distribution and function of phosphatidylserine in cellular membranes. Annu. Rev. Biophys. 39, 407-427 (2010).

36. Liang, Q. \& Zhou, B. Copper and manganese induce yeast apoptosis via different pathways. Mol. Biol. Cell 18, 4741-4749 (2007).

\section{Acknowledgments}

The authors acknowledge financial support from the National Natural Science Foundation of China (No. 10975154 and No. 21072002).

\section{Author contributions}

Z.W. and X.Z. conceived the research. Q.Y. performed the yeast apoptosis experiments. S.X. performed the electrochemical experiments. D.C. gave constructive comments on the results. Z.W. and X.Z. edited the manuscript and provided the research fundings. All authors contributed to writing of the manuscript.

\section{Additional information}

Supplementary information accompanies this paper at http://www.nature.com/ scientificreports

Competing financial interests: The authors declare no competing financial interests

How to cite this article: Yue, Q.L., Xiong, S.Q., Cai, D.Q., Wu, Z.Y. \& Zhang, X. Facile and quantitative electrochemical detection of yeast cell apoptosis. Sci. Rep. 4, 4373; DOI:10.1038/srep04373 (2014).

(C) This work is licensed under a Creative Commons Attributioncc) visit http://creativecommons.org/licenses/by-nc-sa/3.0 